\title{
Phenotypic Detection of AAC(6 $\square$-Ib-Cr Expression in Enterobacteriacae Isolates
}

\author{
Simit Kumar, Maitreyi Bandyopadhyay, Manas Bandyopadhyay, Prabir \\ Mukhopadhyay, Mitali Chatterjee, Sanjeev Das, Sumon Poddar \\ ${ }^{\text {I}}$ (Department Of Microbiology, R.G.Kar Medical College, Kolkata/ West Bengal University Of Health Sciences, \\ India)
}

\begin{abstract}
Background:

Quinolone resistance in Enterobacteriaceae usually results from mutations in genes carried by chromosomally encoded type II topoisomerases, efflux pumps, or porin-related proteins. Since 1998, plasmid-mediated quinolone resistances (PMQR) have been described. Recently, a new mechanism of transferable quinolone resistance was reported: enzymatic inactivation of certain quinolones. $A A C\left(6^{\prime}\right)-I b-c r$ is a variant of $A A C\left(6^{\prime}\right)-I b$ which encodes an aminoglycoside acetyltransferase that confers reduced susceptibility to ciprofloxacin or norfloxacin.. PMQR determinants are often combined with extended-spectrum beta-lactamases (ESBLs) leading to organisms possessing multi drug resistance.

Aims \& Objectives: To study the incidence of $A A C\left(6^{\prime}\right)-I b-c r$ expression in Enterobacteriacae isolates by phenotypic method and to find any correlation between the genetic expression of $A A C\left(6^{\prime}\right)-I b-c r$ along with ESBL production.

Materials and methods: The 430 clinical Enterobacteriaceae isolates exhibiting ciprofloxacin and norfloxacin resistance were included in this study. They were grown in Luria-Bertani Broth ( LB broth) containing norfloxacin $(8 \mu \mathrm{g} / \mathrm{ml})$, with intermittent shaking for $18 \mathrm{~h}$ at $35^{\circ} \mathrm{C}$. Ten microliters of each culture medium was applied on the blank disk set on a Mueller-Hinton agar plate inoculated with E. coli ATCC 25922 and incubated for $18 \mathrm{~h}$ at $35^{\circ} \mathrm{C}$. A significant decrease of a growth-inhibitory zone by $\geq 10 \mathrm{~mm}$ was considered as a positive test for the production of aac(6')-Ib-cr, while aac(6')-Ib-cr production was considered not to be produced in strains which did not show any reduction in the zone of inhibition.

Results: The overall expression of the $A A C\left(6^{\prime}\right)-I b-c r$ did not show much variation with almost half of the isolates from all the different samples showing $A A C\left(6^{\prime}\right)-I b-c r$ production with blood isolates showing a production as high as $66.77 \%$.). A significant association was noted with ESBL production and the simultaneous expression of AAC $\left(6^{\prime}\right)-I b-c r$ in both E.coli $(P$ value $<0.0001)$ and K.pneumoniae isolates $(P$ value $=0.0137$ ) which were the two most predominant isolates in the study. A significant association $(P$ value 0.0442) was observed between aminoglycoside resistance and $A A C\left(6^{\prime}\right)-I b-c r$ expression in E.coli isolates only, while no significant association was observed (P value $=0.7763)$ in K. pneumonia isolates.

Conclusion: $A A C\left(6^{\prime}\right)-I b-c r$, though being a recently described gene has high degree of expression in Enterobacteriaceae isolates, which not only confers resistance to fluroquinolones and aminoglycosides but also is coexpressed with ESBL genes, thus producing a scenario of multi drug resistant organisms, further increasing the burden on our limited armamentarium against these bacteria.
\end{abstract}

Keywords: $A A C\left(6^{\prime}\right)-I b-c r$, ESBL, Enterobacteriacae

\section{Introduction}

Quinolone resistance in Enterobacteriaceae usually results from mutations in genes carried by chromosomally encoded type II topoisomerases, efflux pumps, or porin-related proteins. Since 1998, plasmidmediated quinolone resistances (PMQR) have been described. They have been reported worldwide in unrelated Enterobacterial species and are usually associated with mobile elements. ${ }^{[1]}$ Quinolones and beta-lactams are among the three most commonly used antimicrobials in human therapeutics. PMQR determinants confer lowlevel resistance, but their presence could potentially facilitate evolution of the bacterial host toward higher levels of resistance by mutational alterations in type II topoisomerases. PMQR determinants are often combined with extended-spectrum beta-lactamases (ESBLs). This suggests that there is the potential for selection of $P M Q R$ by the use of beta-lactams and of beta-lactam resistance by the use of quinolones. The Qnr proteins protect DNA from quinolone binding to gyrase and topoisomerase IV. QepA1 and QepA2 are quinolone efflux pump proteins.$^{[2]}$

Recently, a new mechanism of transferable quinolone resistance was reported: enzymatic inactivation of certain quinolones. AAC $\left(6^{\prime}\right)$ - Ib-cr is a variant of $\mathrm{AAC}\left(6^{\prime}\right)-\mathrm{Ib}$ which encodes an aminoglycoside acetyltransferase that confers reduced susceptibility to ciprofloxacin or norfloxacin by $\mathrm{N}$ acetylation of a 
piperazinyl amine. AAC $\left(6^{\prime}\right)$-Ib-cr differs from $\mathrm{AAC}\left(6^{\prime}\right)$-Ib by the following two amino acid substitutions: Trp102Arg and Asp179Tyr which together are necessary and sufficient for the enzyme's ability to acetylate ciprofloxacin. ${ }^{[3,4]}$

When both qnrA and AAC(6')-Ib-cr are present in the same cell, the level of resistance is increased fourfold more than that conferred by qnrA alone, with an MIC of ciprofloxacin of $1.0 \mu \mathrm{g} / \mathrm{ml}$, a value near the clinical breakpoint for susceptibility. In addition, the presence of AAC $\left(6^{\prime}\right)-\mathrm{Ib}-\mathrm{cr}$ alone increased substantially the frequency of selection of chromosomal mutants upon exposure to ciprofloxacin. ${ }^{[3]}$

Since the fluoroquinolone-modifying enzyme gene, $\operatorname{AAC}\left(6^{\prime}\right)-\mathrm{Ib}$-cr, was first reported in 2006 , it has rapidly spread among Enterobacteriaceae clinical isolates worldwide. The presence of AAC $\left(6^{\prime}\right)$-Ib-cr is associated with decreased susceptibility to aminoglycosides (kanamycin, amikacin, and tobramycin) and to norfloxacin and ciprofloxacin. This allelic variant of $a a c\left(\sigma^{\prime}\right)-I b$ was found to be linked to the extended-spectrum $\beta$-lactamase (ESBL) gene $b l a_{\mathrm{CTX}-\mathrm{M}-15}$ in isolates from many countries, while association of $a a c\left(\sigma^{\prime}\right)-I b$ with the bla $_{\text {СTX-M-2 }}$ ESBL gene has been widely reported in Uruguay and Argentina. ${ }^{[5]}$

AAC (6')-Ib-cr may be more widespread than Qnr-determinants. Both, Qnr- and AAC $\left(6^{\prime}\right)$-Ib-cr production are associated with the ESBL production, thus, representing a second mechanism of co-selection of drug-resistance due to exposure to chemically unrelated agents. ${ }^{[5]}$.

Detection of AAC(6 $\left.6^{\prime}\right)-\mathrm{Ib}$-cr has so far depended mainly on genotyping, PCR, and sequencing. Recently, simultaneous high-resolution melting analysis and pyrosequencing were developed for detection. However, these methods are costly and need specialized equipment. Therefore, the availability is limited to highly advanced institutions, such as research laboratories and university hospitals. A phenotypic test validated by Wachino et al. for the detection of AAC has been recently described.. In the present study this costeffective and practical disk-based method was used to look for the presence of $\mathrm{AAC}\left(6^{\prime}\right)-\mathrm{Ib}-\mathrm{cr}$ variant and to detect its association with ESBL production and in clinical isolates of enterobacteria showing resistance or intermediate resistance to ciprofloxacin and norfloxacin. ${ }^{[6]}$

\section{Material \& Methods}

Inclusion criteria: Enterobacteriaceae isolates exhibiting ciprofloxacin and norfloxacin resistance or intermediate resistance as per Clinical Laboratory Standards Institute (CLSI) guidelines by the Kirby Bauer disc diffusion method were included in the study. ${ }^{[7]}$

The 430 clinical isolates included in this study were grown in Luria-Bertani Broth ( LB broth) containing norfloxacin $(8 \mu \mathrm{g} / \mathrm{ml})$, with intermittent shaking for $18 \mathrm{~h}$ at $35^{\circ} \mathrm{C}$. The MIC's of norfloxacin for these strains was $\geq 16 \mu \mathrm{g} / \mathrm{ml}$, and they showed visible growth in liquid broth containing $8 \mu \mathrm{g} / \mathrm{ml}$ of norfloxacin. The broth containing the same concentration of norfloxacin as the other tubes, but lacking any bacteria, was used as the control in this study. Ten microliters of each culture medium was applied on the blank disk set on a MuellerHinton agar plate inoculated with E. coli ATCC 25922 and incubated for $18 \mathrm{~h}$ at $35^{\circ} \mathrm{C}$. The result is shown in Figure 1. When the control medium was applied, an 18-millimeter growth-inhibitory zone (corresponding to 80 ng norfloxacin per disk) was observed. A significant decrease of a growth-inhibitory zone by $\geq 10 \mathrm{~mm}$ was considered as a positive test for the production of $a a c\left(6^{\prime}\right)-I b-c r$, while $a a c\left(6^{\prime}\right)-I b-c r$ production was considered not to be produced in strains which did not show any reduction in the zone of inhibition.

The decrease in zone diameter is an indicator of $a a c\left(6^{\prime}\right)-I b-c r$ production and would be attributed to the inactivation of norfloxacin in the culture medium by the AAC(6_)-Ib-cr enzyme produced during growth.

ESBL detection; ESBL detection was performed as per the CLSI guidelines using ceftazidime, ceftazidime + clavulanic acid and cefotaxime , cefotaxime+ clavulanic acid and by the disc approximation technique. ${ }^{[7]}$

\section{Results}

Of the 430 isolates included in the study, most of the isolates in the study were from pus samples $231(53.72 \%)$ followed by urine $14(33.72 \%)$, respiratory samples $34(7.9 \%)$, body fluids $14(3.26 \%)$ and blood cultures $6(1.40 \%)\left(\right.$ Table1). The overall expression of the $\mathrm{AAC}\left(6^{\prime}\right)$-Ib-cr did not show much variation with almost half of the isolates from all the different samples showing $\mathrm{AAC}\left(6^{\prime}\right)$-Ib-cr production with blood isolates showing a production as high as $66.77 \%$. (Table1).

Among the different isolates $E$. coli was the predominant isolate(256/444) followed by K.pneumoniae (106/444), P. mirabilis, Citrobacter spp. K.oxytoca and Enterobacter spp.. All the isolates showed a high incidence of $\mathrm{AAC}\left(6^{\prime}\right)-\mathrm{Ib}$-cr production, with almost half of all the isolates producing the fluroquinone modifying enzyme, with P.mirabilis being the only exception which showed a low incidence of $14.29 \%$ only. The overall expression of the AAC(6')-Ib-cr was 218/430(50.70\%). (Table 2). 
ESBL production was noted in 142/256 (55.47\%) of E. coli isolates and 62/106(58.49\%) of K. pneumonia isolates. A significant association was noted with ESBL production and the simultaneous expression of AAC $\left(6^{\prime}\right)$-Ib-cr in both E.coli $(\mathrm{P}$ value $<0.0001)$ and K.pneumoniae isolates $(\mathrm{P}$ value $=0.0137)$ which were the two most predominant isolates in the study (Table 3).

Aminoglycoside resistance was noted in 79/256 (30.86\%) of the E.coli isolates and 63/106 (59.43\%) of $\mathrm{K}$. pneumonia isolates but a significant association ( $\mathrm{P}$ value 0.0442 ) was observed between aminoglycoside resistance and $\mathrm{AAC}\left(6^{\prime}\right)-\mathrm{Ib}-\mathrm{cr}$ expression in E.coli isolates only, while no significant association was observed $(\mathrm{P}$ value $=0.7763)$ in $\mathrm{K}$. pneumonia isolates $($ Table 4$)$.

The overall incidence of AAC(6)-Ib-cr expression of 50.70\% and 53.91\% in E. coli was noted in this study, which corresponds to the findings of Robicsek AJ et al. In China. The study found an incidence of $53.91 \%$ in E. coli and $52.83 \%$ in K. pneumonia, which is much higher than the findings of $32 \%$ of E. coli, $16 \%$ of K. pneumoniae, $7.5 \%$ of Enterobacter, reported by Park et al. The study finds a very high association with ESBL production similar to the results of Warburg et al. who observed that $68.8 \%$ of aac $\left(6^{\prime}\right)-\mathrm{Ib}-\mathrm{cr}+\mathrm{ve}$ isolates were ESBL producer. Table 5 denotes the different studies that have been carried out worldwide regarding incidence of AAC(6')-Ib-cr expression

\section{Discussion}

The emergence of new mechanisms of quinolone resistance, namely, those caused by the horizontal transfer of resistance genes on mobile genetic elements, are of great concern since they bring new possibilities for the spread of resistance. ${ }^{[8]}$

According to data from the European surveillance of antimicrobial consumption, as the defined daily dose (DDD)/1,000 inhabitants per day of ciprofloxacin increased slightly from $0.5 \mathrm{DDD} / 1,000$ inhabitants per day in 1997 to $0.6 \mathrm{DDD} / 1,000$ inhabitants per day in 2003, there was a constant increase in resistance to fluoroquinolones. In the isolates included in this study, the percentage of ciprofloxacin -resistant ESBL positive isolates was high and a decrease of the ciprofloxacin intermediate resistance phenotype was observed along with the emergence of the $a a c\left(6_{-}\right)-I b-c r$ gene as detected by phenotypic methods. This suggests, a role for this low-level PMQR gene in enhancing the selection of chromosomal mutations and resulting in the occurrence and dissemination of clinically relevant resistance levels. ${ }^{[9]}$ Additionally, prior quinolone use is a risk factor for subsequent infection with quinolone-resistant, ESBL-producing organisms. ${ }^{[10]}$

The overall incidence of AAC(6)-Ib-cr expression of 50.70\% and 53.91\% in E. coli was noted in this study, which corresponds to the findings of Robicsek AJ et al. ${ }^{[11]}$ In China. The study found an incidence of $53.91 \%$ in E. coli and $52.83 \%$ in K. pneumonia, which is much higher than the findings of $32 \%$ of E. coli, $16 \%$ of K. pneumoniae, $7.5 \%$ of Enterobacter, reported by Park et al. ${ }^{[3]}$ The study finds a very high association with ESBL production similar to the results of Warburg et al. ${ }^{[12]}$ who observed that $68.8 \%$ of AAC $\left(6^{\prime}\right)-\mathrm{Ib}$-cr isolates were ESBL producer

In this study a significant association of aminoglycoside resistance with $\mathrm{AAC}\left(6^{\prime}\right)$-Ib-cr was noted in case of E. coli but similar association was not noted in case of Klebsiella probably because of the fact that the AAC $\left(6^{\prime}\right)-\mathrm{Ib}$-cr confers resistance to kanamycin but not to gentamicin which was not tested in this particular study. ${ }^{[10]} \mathrm{A}$ high incidence of $42 \%$ of 31 gentamicin-resistant isolates harboring AAC $\left(6^{\prime}\right)$-Ib-cr, was also noted by Park et al. ${ }^{[3]}$

The most striking finding of our study was the wide penetration of the $\mathrm{AAC}\left(6^{\prime}\right)$-Ib-cr allele in nearly half of all the Enterobacteriacaea isolates, E. coli (53.91\%), Klebsiella pneumonia (52.83\%), Klebsiella oxytoca (57. 14\%), Enterobacter sp. (60\%). Although this variant gene was not reported until 2006, it was already present in more than half of multidrug-resistant E. coli isolates in Shanghai, China, in 2000 to 2001, and it is now present in the majority of census regions of the United States. The various antibiograms and the range of species of the isolates studied suggest that the dissemination of AAC(6')-Ib-cr does not occur through clonal spread or the spread of a single plasmid. The diversity of plasmids on which this gene circulates is not yet known, but its presence as part of an integron cassette suggests that it could be widely mobile among plasmids. Selection pressures from the use of aminoglycosides that are enzyme substrates (kanamycin, tobramycin, and amikacin) and the use of quinolones with a piperazinyl amine that is subject to $N$-acetylation by the $\mathrm{cr}$ variant enzyme would be predicted to promote gene prevalence but have not yet been studied in clinical settings. ${ }^{[3]}$

Warburg et al. had also demonstrated an epidemiologic link between AAC(6')-Ib-cr and CTX-M ESBL. Our findings support earlier suggestions of a linkage between AAC(6')-Ib-cr and ESBLs and raise the possibility that the use of ciprofloxacin - a widely prescribed fluoroquinolone in the world - is a driver of both fluoroquinolone resistance and the emergence of CTX-M ESBLs. The present increase in multi drug resistance could be hypothesised to the fact that increase in $\beta$ lactams consumption leads to increase in ESBL production, which in turn is increases the $a a c\left(6^{\prime}\right)-I b-c r$ gene expression and vice a versa and the aac $\left(6^{\prime}\right)-I b-c r$ gene expression is in turn linked with aminoglycoside resistance, thus by administering any class of quinolones or $\beta$ 
lactams is in turn leading to development of multidrug resistance organisms in the community as well as the hospital setup (Figure 2). ${ }^{[11]}$

There have been studies which indicate horizontal transfer of a $a c\left(6 \_\right)-I b-c r$ among the Enterobacteriaceae. The $a a c\left(6^{\prime}\right)-\mathrm{Ib}-\mathrm{cr}$ gene showed a high association with $\beta$ lactamase genes, including OXA1, CTX-M-3 or -15 , and TEM-1, in isolates from Korea. This is an alarming finding indicating that the spread of this gene would only increase in the years to come. $\left[{ }^{4]}\right.$

Larger studies could be undertaken to see the geographical distribution of the fluroquinolone modifying enzyme.

There have been reports of $q n r B$ and $a a c\left(6^{\prime}\right)-I b-c r$ coexpression in clinical Enterobacteriaceae isolates from a Bulgarian hospital. The study also concluded that $a a c\left(6^{\prime}\right)-I b-c r$ might already be widespread and substantially more prevalent than $q n r$ genes. If the incidence of coexpression of both these genes were to increase then that could lead to very high incidence of quinolone resistance. ${ }^{[13]}$

There have been various methods described for identification of $a a c\left(6_{-}\right)-I b-c r$ including genotyping, PCR, and sequencing. Recently, simultaneous high-resolution melting analysis and pyrosequencing, which have restraints of the cost associated with the tests and the fact that these tests are usually available with reference laboratories. We conclude that this phenotypic method is a simple method for identification of aac $\left(6^{\prime}\right)$ $I b-c r$ producers and that it would be of great assistance in screening for $a a c\left(6^{\prime}\right)-I b-c r$ producers and their epidemiology in clinical microbiology laboratories, with resource limited settings.

\section{FIGURES \& TABLES}

Significant decrease of a growth-inhibitory zone $(>10 \mathrm{~mm})$ signified aac $\left(6^{\prime}\right)$-Ib-cr-positive isolates.

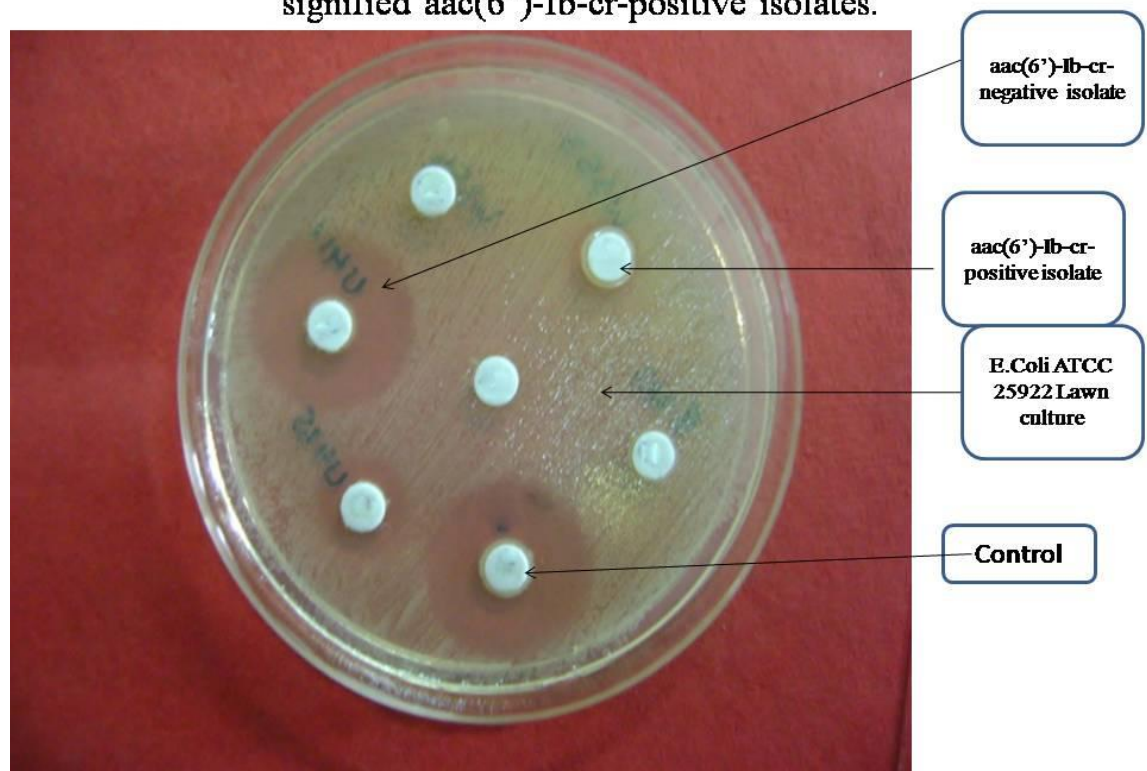

Figure 1: Significant decrease of a growth-inhibitory zone $(>10 \mathrm{~mm})$ signified aac $\left(6^{\prime}\right)$-Ib-cr-positive isolates.

Table 1: Sample wise distribution of Isolates producing Fluoroquinolone - Modifying Enzyme AAC(6')-Ib-cr

\begin{tabular}{|c|c|c|c|}
\hline Samples & $\begin{array}{l}\text { Total } \\
\mathbf{N}=\mathbf{4 3 0}\end{array}$ & $\begin{array}{l}\text { Isolates producing } \\
\text { Fluoroquinolone } \\
\text { Modifying Enzyme } \\
\text { AAC(6')-Ib-cr }\end{array}$ & $\begin{array}{l}\text { Isolates not } \quad \text { producing } \\
\text { Fluoroquinolone }- \\
\text { Enzyme AAC(6')-Ib-cr }\end{array}$ \\
\hline Urine & $145(33.72 \%)$ & $80(55.17 \%)$ & 65 \\
\hline Wound / Pus & $231(53.72 \%)$ & $102(44.16 \%)$ & 129 \\
\hline $\begin{array}{l}\text { Throat Swab / Sputum / ET } \\
\text { tube suction }\end{array}$ & $34(7.9 \%)$ & $18(52.94 \%)$ & 16 \\
\hline Blood & $6(1.40 \%)$ & $4(66.67 \%)$ & 2 \\
\hline $\begin{array}{lll}\text { Body cavity fluids } & \text { (e.g. } \\
\text { pleural fluid) }\end{array}$ & $14(3.26 \%)$ & $6(42.86 \%)$ & 8 \\
\hline
\end{tabular}

Among the 430 isolates included in this study, most of the isolates showing fluroquinolone resistance or intermediate resistance were obtained from pus samples $(53.72 \%)$, followed by urine $(33.72 \%)$., but the overall expression of the AAC(6')-Ib-cr did not show much variation with almost half of the isolates from 
different samples showing $\mathrm{AAC}\left(6^{\prime}\right)-\mathrm{Ib}$-cr production, with blood isolates showing a production as high as $66.77 \%$.

Table 2: Organism wise distribution of AAC(6')-Ib-cr expression.

\begin{tabular}{|c|c|c|c|}
\hline $\begin{array}{ll}\text { Quinolone } & \text { resistant } \\
\text { Organisms } & \\
\end{array}$ & $\begin{array}{l}\text { Total number } \\
\text { of isolates } \\
(\mathrm{N}=\mathbf{4 3 0})\end{array}$ & $\begin{array}{lr}\text { Isolates } & \text { producing } \\
\text { Fluoroquinolone } & - \\
\text { Modifying Enzyme } & \text { AAC(6')-Ib-cr }\end{array}$ & $\begin{array}{l}\text { Isolates without producing } \\
\text { Fluoroquinolone }- \text { Modifying } \\
\text { Enzyme AAC(6')-Ib-cr }\end{array}$ \\
\hline Escherichia coli & 256 & $138 / 256(53.91 \%)$ & 118 \\
\hline Klebsiella pneumoniae & 106 & $\begin{array}{ll}56 / 106 & (52.83 \%) \\
\end{array}$ & 50 \\
\hline Klebsiella oxytoca & 14 & $8 / 14 \quad(57.14 \%)$ & 6 \\
\hline Enterobacter $s p$. & 10 & $(60 \%)$ & 4 \\
\hline Proteus mirabilis & 28 & $(14.29 \%)$ & 24 \\
\hline Citrobacter sp. & 16 & $(37.5 \%)$ & 10 \\
\hline
\end{tabular}

Among the different isolates E. coli was the predominant isolate $(59.53 \%)$ followed by K.pneumoniae (24.65\%). All the isolates showed a high incidence of AAC(6')-Ib-cr production, with almost half of all the isolates producing the fluroquinone modifying enzyme, with P.mirabilis being the only exception which showed a low incidence of $14.29 \%$ only. The overall expression of AAC(6')-Ib-cr among all the isolates was $218 / 430(50.70 \%)$.

Table 3: Distribution of ESBL production observed in different isolates

\begin{tabular}{|c|c|c|c|}
\hline Escherichia coli (Total 256) & $\begin{array}{l}\text { Isolates producing Fluoroquinolone } \\
\text { - Modifying Enzyme AAC(6')-Ib- } \\
\text { cr }\end{array}$ & $\begin{array}{lll}\text { Isolates without } & \text { producing } \\
\text { Fluoroquinolone }- & \text { Modifying } \\
\text { Enzyme AAC(6')-Ib-cr } & \\
\end{array}$ & $\mathrm{P}$ value $<0.0001$ \\
\hline ESBL + & $106(41.4 \%)$ & $36(14.06 \%)$ & \\
\hline ESBL - & $32(12.5 \%)$ & $82(32.03 \%)$ & \\
\hline Chi-square 55.21, df - 1 & OR-7.545 & $95 \%$ C.I. $=4.324$ to 13.17 & \\
\hline $\begin{array}{l}\text { Klebsiella pneumoniae (Total } \\
\text { 106) }\end{array}$ & $\begin{array}{l}\text { Isolates producing Fluoroquinolone } \\
\text { - Modifying Enzyme AAC(6')-Ib- } \\
\text { cr }\end{array}$ & $\begin{array}{lll}\text { Isolates without } & \text { producing } \\
\text { Fluoroquinolone }- & \text { Modifying } \\
\text { Enzyme AAC }\left(6^{\prime}\right)-\mathrm{Ib}-\mathrm{cr} & \\
\end{array}$ & $\begin{array}{l}\mathrm{P} \text { value } \\
0.0137\end{array}$ \\
\hline ESBL + & $39(36.79 \%)$ & $23(29.69 \%)$ & \\
\hline ESBL - & $17(16.04 \%)$ & $27(25.47 \%)$ & \\
\hline Chi-square $6.082, \mathrm{df}-1$ & $\mathrm{OR}-2.693$ & $95 \% \mathrm{CI}=1.215$ to 5.971 & \\
\hline
\end{tabular}

ESBL production was noted in $142 / 256(55.47 \%)$ of $E$. coli isolates and 62/106(58.49\%) of $K$. pneumonia isolates. A significant association was noted with ESBL production and the simultaneous expression of AAC(6')-Ib-cr in both E.coli (P value $<\mathbf{0 . 0 0 0 1 )}$ and K.pneumoniae isolates (P value $=\mathbf{0 . 0 1 3 7}$ ) which were the two most predominant isolates in the study.

Table 4: Distribution of aminoglycoside resistance and AAC(6')-Ib-cr production observed in different isolates

\begin{tabular}{|c|c|c|c|}
\hline Escherichia coli (Total 256) & $\begin{array}{l}\text { Isolates } \quad \begin{array}{r}\text { producing } \\
\text { Fluoroquinolone }\end{array}-\text { Modifying } \\
\text { Enzyme AAC(6')-Ib-cr }\end{array}$ & $\begin{array}{l}\text { Isolates without } r \text { producing } \\
\text { Fluoroquinolone }- \text { Modifying Enzyme } \\
\text { AAC }\left(6^{\prime}\right)-\mathrm{Ib}-\mathrm{cr}\end{array}$ & $\mathrm{P}$ value 0.0442 \\
\hline Aminoglycoside resistance + & $50(19.53 \%)$ & $29(11.33 \%)$ & \\
\hline Aminoglycoside resistance - & $88(34.38 \%)$ & $89(34.76 \%)$ & \\
\hline Chi-square $4.050, \mathrm{df}-1$ & $\mathrm{OR}=1.744$ & $95 \% \mathrm{CI}=1.012$ to 3.005 & \\
\hline Klebsiella pneumoniae (Total 106) & 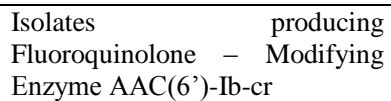 & $\begin{array}{l}\text { Isolates without producing } \\
\text { Fluoroquinolone - Modifying Enzyme } \\
\text { AAC }\left(6^{\prime}\right) \text {-Ib-cr }\end{array}$ & $\mathrm{P}$ value 0.7763 \\
\hline Aminoglycoside resistance + & $34(32.08 \%)$ & $29(27.36 \%)$ & \\
\hline Aminoglycoside resistance - & $22(20.75 \%)$ & $21(19.81 \%)$ & \\
\hline Chi-square $0.08072, \mathrm{df}-1$ & $\mathrm{OR}=1.119$ & $95 \% \mathrm{CI}=0.5147$ to 2.433 & \\
\hline
\end{tabular}

Aminoglycoside resistance was noted in 79/256 (30.86\%) of the E.coli isolates and 63/106 (59.43\%) of $\mathrm{K}$. pneumonia isolates but a significant association $\mathrm{P}$ value 0.0442 was observed between aminoglycoside resistance and $\mathrm{AAC}\left(6^{\prime}\right)-\mathrm{Ib}-\mathrm{cr}$ expression in E.coli isolates only, while no significant association was observed $\mathrm{P}$ value 0.7763 in $\mathrm{K}$. pneumonia isolates.

Table 5: Comparison of various studies conducted for detection of AAC(6')-Ib-cr incidence

\begin{tabular}{|l|l|l|l|l|}
\hline Author & AAC(6')-Ib-cr & Year & Place & Others \\
\hline Stefana Sabtcheva et al. & $\begin{array}{l}52.5 \% \text { isolates of 163 ESBL } \\
\text { producer }\end{array}$ & 2005 & Bulgaria & \\
\hline
\end{tabular}




\begin{tabular}{|c|c|c|c|c|}
\hline Chi Hye Park et al. & $\begin{array}{l}32 \% \text { of E. coli, } 16 \% \text { of } \mathrm{K} . \\
\text { pneumoniae, } \\
\text { Enterobacter }\end{array}$ & $\begin{array}{l}1999 \\
2004\end{array}$ & USA & $\begin{array}{l}42 \% \text { of } \\
\text { gentamicin- } \\
\text { resistant isolates } \\
\text { harbored } \\
\text { aac(6')-Ib-cr }\end{array}$ \\
\hline Robicsek AJ et al. & $51 \%$ of E. coli & $\begin{array}{l}2000 \\
2001\end{array}$ & China & \\
\hline Gabriela Warburg et al. & $\begin{array}{l}1991-1997, \text { none, } 1998-2005 \\
\text { onwards, } 7.1 \% \text { of the total } \\
\text { isolates }\end{array}$ & $\begin{array}{l}1991 \\
2005\end{array}$ & Israel & $\begin{array}{l}68.8 \% \text { of } \\
\text { aac }\left(6^{\prime}\right)-\mathrm{Ib}-\mathrm{cr}+\mathrm{ve} \\
\text { isolates } \\
\text { were } \\
\text { producer. }\end{array}$ \\
\hline This study & $\begin{array}{l}2012-2013 \\
53.91 \% \text { of } \text { E. coli and } 52.83 \% \text { of } \\
\text { K. pneumonia, overall } 218 / \\
430(50.70 \%)\end{array}$ & $\begin{array}{l}2012- \\
2013\end{array}$ & India & $\begin{array}{l}73.98 \% \text { of } \\
\text { aac(6')-Ib-cr +ve } \\
\text { isolates } \\
\text { were } \\
\text { producer }\end{array}$ \\
\hline
\end{tabular}

The overall incidence of AAC(6')-Ib-cr expression of $50.70 \%$ and $53.91 \%$ in E. coli was noted in this study, which corresponds to the findings of Robicsek AJ et al. In China. The study found an incidence of $53.91 \%$ in E. coli and $52.83 \%$ in K. pneumonia, which is much higher than the findings of $32 \%$ of E. coli, $16 \%$ of K. pneumoniae, $7.5 \%$ of Enterobacter, reported by Park et al. The study finds a very high association with ESBL production similar to the results of Warburg et al. who observed that $68.8 \%$ of aac(6')-Ib-cr +ve isolates were ESBL producer

\section{Conclusion}

AAC $\left(6^{\prime}\right)$-Ib-cr, though being a recently described gene has high degree of expression in Enterobacteriaceae isolates, which not only confers resistance to fluroquinolones and aminoglycosides but also is coexpressed with ESBL genes, thus producing a scenario of multi drug resistant organisms, further increasing the burden on our limited armamentarium against these bacteria.

\section{References}

[1]. Robicsek, A., Jacoby G,Hooper D. The worldwide emergence of plasmid-mediated quinolone resistance. Lancet Infect Dis, 6(10), 2006, 629-40.

[2]. Guillard T, Duval V, Moret H, Brasme L, Vernet-Garnier V, de Champs Ch. Rapid Detection of aac(6 )-Ib-cr Quinolone Resistance Gene by Pyrosequencing. J Clin Microbiol, 48(1), 2010, 286-289.

[3]. Park CH, Robicsek A, Jacoby GA, Sahm D, Hooper DC. Prevalence in the United States of aac(6')-Ib-cr encoding a ciprofloxacinmodifying enzyme. Antimicrob Agents Chemother, 50(11), 2006, 3953-3955.

[4]. Kim ES, Jeong JY, Jun JB, Choi SH, Lee SO, Kim MN, et al. Prevalence of aac(6_--Ib-cr Encoding a Ciprofloxacin-Modifying Enzyme among Enterobacteriaceae Blood Isolates in Korea. Antimicrob Agents Chemother, 53(6), 2009, 2643-2645.

[5]. Hawkey P. Mechanisms of quinolone action and microbial response. J. Antimicrob. Chemother, 51(1), 2003, 29-35.

[6]. Wachino J, Yamane K, and Arakawa Y. Practical Disk-Based Method for Detection of Escherichia coli Clinical Isolates Producing the Fluoroquinolone-Modifying Enzyme AAC(6_)-Ib-cr. J Clin Microbiol, 49(6), 2011, 2378-9.

[7]. Performance standards for Antimicrobial Susceptibility Testing; Seventeenth Informational Supplement. Clinical Laboratory Standards Institute 2010;M100-S20;29:46-48.

[8]. Cavaco LM, Aarestrup FM. Evaluation of Quinolones for Use in Detection of Determinants of Acquired Quinolone Resistance, Including the New Transmissible Resistance Mechanisms qnrA, qnrB, qnrS, and aac(6_)Ib-cr, in Escherichia coli and Salmonella enterica and Determinations of Wild-Type Distribution. J Clin Microbiol. 2009;47:2751-2758.

[9]. Avgustin A, Keber R, Zerjavic K, Orazem T, Grabnar M. Emergence of the Quinolone Resistance-Mediating Gene aac(6_)-Ib-cr in Extended-Spectrum $\beta$ Lactamase-Producing Klebsiella Isolates Collected in Slovenia between 2000 and 2005. Antimicrob Agents Chemother, 51(11), 2007, 4171-4173.

[10]. Paterson D. "Collateral Damage" from Cephalosporin or Quinolone Antibiotic Therapy. Clin Infect Dis. (2004) 38 (Supplement 4): S341-S345

[11]. Robicsek A, Strahilevitz J, Jacoby G, Macielag M, Abbanat D, Bush K et al.. Fluoroquinolone modifying enzyme: a novel adaptation of a common aminoglycoside acetyltransferase. Nat. Med, 12(1), 2006, 83- 8

[12]. Warburg G, Korem M, Robicsek A, Engelstein D, Moses A, Block C, et al. Changes in aac(6_-lb-cr Prevalence and Fluoroquinolone Resistance in Nosocomial Isolates of Escherichia coli Collected from 1991 through 2005. Antimicrob. Agents Chemother, 53(3), 2009, 1268-1270

[13]. Sabtcheva S, Kaku M. High Prevalence of the aac(6_)-Ib-cr Gene and Its Dissemination among Enterobacteriaceae Isolates by CTX-M-15 Plasmids in Bulgaria. Antimicrob Agents Chemother, 53(1), 2009, 335-336. 